\title{
ANALISA FAKTOR RESIKO CONSTRUCTION WASTE PADA PROYEK KONSTRUKSI DI KOTA PADANG
}

\author{
Monika Natalia ${ }^{1)}$, Yan Partawijaya ${ }^{2)}$, Zulfira Mirani ${ }^{3)}$ \\ ${ }^{1}$ Teknik Sipil, Politeknik Negeri Padang \\ monikanatalia75@gmail.com \\ ${ }^{2}$ Teknik Sipil, Politeknik Negeri Padang \\ yan_parta21@yahoo.com \\ 3 Teknik Sipil, Politeknik Negeri Padang \\ raninawaf@gmail.com
}

\begin{abstract}
Abstrak
Waste atau disebut juga nonvalue-adding activity adalah semua aktivitas yang tidak memberikan nilai tambah dimata customer pada suatu produk yang diproses (Hines dan Taylor, 2000). Tujuan penelitian ini adalah melakukan identifikasi waste yang terjadi pada proyek konstruksi di Kota Padang.

Metode Penelitian yang digunakan analisis deskriptif menggunakan quisioner dengan data proyek konstruksi yang sedang atau sudah dikerjakan di Kota Padang. Adapun respondennya adalah proyek manager, site manager, site engineer, quality control, supervisor, pelaksana lapangan dan pengawas lapangan. Dari quisioner yang kembali, dilakukan pengujian data dengan menggunakan SPSS. Pengujian data meliputi uji validasi, uji reliabilitas dan uji korelasi. Selanjutnya dilakukan analisis regresi linier variabel berganda, yang bertujuan untuk mengetahui factor-faktor yang berpengaruh besar terhadap waste. proyek konstruksi di kota Padang.

Quisioner yang disebarkan sebanyak 25 quisioner. Response rate 100\%. Dari data penelitian terdapat 7 faktor dengan 44 variabel. Hasil uji validasi, didapatkan 5 faktor dan 37 variabel yang valid. Hasil uji reliabilitas, teridentifikasi 5 faktor dengan 14 variabel yang reliable. Hasil uji korelasi, semua variable reliable juga terkorelasi dengan kuat. Analisa regresi dilakukan dengan uji $\mathrm{R}^{2}$, uji $\mathrm{F}$ dan uji t. Dari hasil uji $\mathrm{R}^{2}$, didapatkan besarnya kontribusi 14 variabel terhadap waste konstruksi sebesar 91,6\%. Hasil uji F memperlihatkan secara simultan semua variabel mampu menjelaskan hubungannya terhadap penyimpangan biaya dengan sangat baik. Hal ini ditunjukkan oleh signifikasi $<5 \%$. Hasil dari uji t, teridentifikasi 5 faktor dengan 8 variabel yang signifikan. Variabel tersebut adalah adalah waktu menunggu revisi gambar/perubahan desain sebesar 0,782 , mutu pengawasan rendah sebesar 0,430, kesalahan pada saat pelaksanaan pekerjaan sebesar 1,957, keterlambatan pelaksanaan pekerjaan sebesar 2,122, pekerjaan rework dan repair sebesar 0,556, perencanaan dan penjadwalan yang buruk sebesar 2,730, perubahan desain sebesar 0,863 dan cuaca sebesar 0,966. Hasil penelitian ini nantinya diharapkan dapat sebagai bahan pertimbangan untuk semua pihak yang terlibat dalam pelaksanaan proyek konstruksi guna menghindari biaya-biaya tambahan yang tidak diinginkan dan menghindari keterlambatan penyelesaian proyek akibat waste konstruksi.
\end{abstract}

Kata kunci : waste, non-value adding activities, proyek konstruksi 


\section{PENDAHULUAN}

\subsection{Latar Belakang}

Waste adalah setiap bentuk in-efisiensi sebagai akibat dari penggunaan alat, material, tenaga kerja atau modal dalam jumlah yang besar lebih dari yang seharusnya (Koskela, 1992). Waste dalam industri konstruksi diantaranya adalah penundaan, quality cost, kurangnya keamanan, mengulang pekerjaan, aktivitas yang tidak perlu, lokasi proses/tahapan antar pekerjaan jaraknya berjauhan, pemilihan yang tidak tepat untuk metode pekerjaan/alat yang digunakan, buruknya proses pekerjaan itu sendiri (Serpell, 1995).

Waste yang ditimbulkan selama proses konstruksi tidak hanya mempengaruhi produktivitas proyek, tetapi juga memberikan dampak yang tidak baik terhadap lingkungan di sekitarnya. Oleh karena itu, perlu diadakan penelitian tentang faktor-faktor penyebab terjadinya waste pada proyek konstruksi, khususnya di Kota Padang, sehingga resiko waste yang terjadi dapat diminimalisir secepat mungkin.

Nantinya penelitian ini diharapkan dapat menjadi masukan bagi pengajar dan mahasiswa, dan bagi kontraktor dengan diketahui penyebab terjadinya waste maka resiko pada saat pelaksanaan proyek konstruksi untuk dapat dikurangi sehingga meningkatkan produktivitas proyek.

\subsection{Rumusan Masalah}

1. Bentuk waste atau pemborosan apa saja yang sering terjadi pada proyek konstruksi di Kota Padang?

2. Waste apa saja yang memiliki efek/dampak tertinggi terhadap pelaksanaan proyek konstruksi?

3. Waste mana yang dianggap paling penting oleh responden?

4. Apa factor-faktor yang sering menjadi penyebab terjadinya waste pada proyek konstruksi di Kota Padang?

\subsection{Hipotesis}

Terjadinya penambahan/pembengkakan biaya proyek dan terjadinya keterlambatan waktu penyelesaian proyek di Kota Padang, disebabkan oleh waste pada saat pelaksanaan. Hipotesis awal, disebabkan oleh :

1. Penundaan pekerjaan

2. kurangnya keamanan,

3. Mengulang pekerjaan,

4. lokasi proses/tahapan antar pekerjaan jaraknya berjauhan,

5. Pemilihan metode pelaksanaan yang tidak tepat

\subsection{Tujuan Penelitian}

1. Mengetahui bentuk waste atau pemborosan yang sering terjadi pada proyek konstruksi di Kota Padang.

2. Mengetahui waste atau pemborosan yang paling mempengruhi kinerja pelaksanaan proyek konstruksi di Kota Padang.

3. Mengetahui waste dengan tingkat bobot tertinggi pada proyek konstruksi di Kota Padang.

4. Mengetahui factor-faktor yang sering menjadi penyebab terjadinya waste atau pemborosan pada proyek konstruksi di Kota Padang.

\subsection{Manfaat Penelitian}

1. Dapat memberikan informasi mengenai waste atau pemborosan yang terjadi beserta factor-faktor penyebabnya pada proyek konstruksi di Kota Padang.

2. Dengan mengetahui bentuk waste dan factor penyebabnya, pihak-pihak yang berperan dalam berlangsungnya suatu proyek konstruksi diharapkan dapat mengurangi terjadinya waste dalam pelaksanaan proyek konstruksi nantinya, sehingga dapat meningkatkan performa dan prosuktivitas proyek. 


\section{TINJAUAN PUSTAKA}

\subsection{Waste (Pemborosan)}

Waste didefenisikan sebagai semua aktivitas yang memerlukan biaya, secara langsung maupun tidak langsung, memerlukan waktu, sumber daya atau membutuhkan persediaan yang tidak memberikan nilai tambah (Alarcon, 1994).

Waste dapat juga digambarkan sebagai segala aktivitas manusia yang menyerap sumber daya dalam jumlah tertentu tetapi tidak menghasilkan nilai tambah, seperti kesalahan yang membutuhkan pembetulan, hasil produksi yang tidak diinginkan oleh pengguna, proses atau pengolahan yang tidak perlu, pergerakan tenaga kerja yang tidak berguna dan menunggu hasil akhir dari kegiatan-kegiatan sebelumnya (Womack and Jones, 2006).

Ohno (1988) mengklasifikasikan pemborosn (waste) dalam 7 kategori :

1. Waste of Waiting, waktu menunggu adalah pemborosan (misalnya : menunggu material datang, menunggu instruksi dan lain-lain).

2. Waste of Overproduction, membuat produk yang lebih banyak dari permintaan.

3. Waste of Overprocessing, proses yang lebih dari yang diinginkan (misalnya : inventory yang rusak akibat penyimpanan atau transportasi sehingga memerlukan proses tambahan re-packing.

4. Waste of Defect, reject atau repair merupakan pemborosan yang dapat secara langsung bisa dilihat.

5. Waste of Motion, gerakan yang tidak perlu dan tidak ergonomis sehingga menambah waktu proses.

6. Waste of Inventory, semakin banyak persediaan disimpan akan semakin banyak pemborosan berupa nilai persediaan yang diam (tidak produktif), nilai ruang yang harus disediakan, beban administrasi pengelolaan dan lain-lain.
7. Waste of Transportation, pemborosan yang diakibatkan oleh transportasi yang tidak teratur.

\subsection{Waste pada Proyek Konstruksi}

Waste pada bidang konstruksi dapat diartikan sebagai kehilangan atau kerugian berbagai sumber daya yaitu material, waktu dan modal/materi, yang diakibatkan oleh kegiatankegiatan yang membutuhkan biaya secara langsung maupun tidak langsung tetapi tidak menambah nilai kepada produk akhir bagi pihak pengguna jasa konstruksi (Formoso et al, 2002).

Waste juga merupakan bentuk ketidakefisienan yang terjadi akibat penggunaan peralatan, tenaga kerja, material, biaya yang melebihi/tidak sesuai dengan yang dibutuhkan dalam pelaksanaan proyek konstruksi. Menurut Alwi et al (2002), kategori waste yang utama dalam bidang konstruksi adalah reworks/repair, rusak/cacat, pemborosan material yang tidak perlu, pergerakan/perpindahan yang tidak perlu, ketidaktepatan dalam pemilihan metode kerja dan manajemen peralatan. Waste pada proyek konstruksi akan mempengaruhi tingkat produktivitas pelaksanaan proyek.

Menurut Al Moghany (2008), waste (non value-adding activity) dapat dibagi menjadi :

1. Contributory Activities

Merupakan aktivitas/bagian pekerjaan yang tidak secara langsung menambah nilai tambah pada hasil akhir namun dibutuhkan dan terkadang merupakan hal penting dalam proses pelaksanaannya.

Contoh : Penanganan material di lokasi, membaca gambar, menerima instruksi dan sebagainya.

Namun jika aktivitas tersebut dilaksanakan dengan tidak tepat/efisien, maka aktivitas tersebut dapat menghambat proses pekerjaan dan menjadi bentuk atau penyebab waste.

\section{Unproductive Activities}


Merupakan aktivitas yang sama sekali tidak dibutuhkan dalam pelaksanaan pekerjaan dan seharusnya dihindari.

Contoh : Pergerakan/perpindahan tenaga kerja dan material yang tidak perlu, menganggur, pekerjaan ulang (rework) karena adanya kesalahan dan lain-lain.

\subsection{Faktor Penyebab Waste}

Menurut Alwi et al (2002), variable/factor yang dapat menyebabkan waste adalah :

1. Poor conditions of something (equipment, materials, environment)

2. A lack of doing something (methods, ineffective, misuse)

3. Poor conditions of human resources (behaviors, skills, qualifications, experience)

Alwi et al (2002) membagi factor penyebab waste dalam enam kelompok yaitu :

1. Manusia

2. Manajemen

3. Desain dan Dokumentasi

4. Material

5. Pelaksanaan

6. Eksternal

Menurut Asiyanto, khusus tentang waste material terjadi karena disebabkan oleh :

\section{Penyusutan Quantity}

Penyusutan quantity dapat terjadi pada saat transportasi ke site dan pada saat pembongkatan material untuk ditempatkan pada gudang atau lokasi penumpukan. Penyusutan quantity juga dapat terjadi pada proses pemindahan material dari satu tempat ke tempat lain dalam lokasi proyek terutama untuk material lepas seperti pasir dan kerikil.

2. Quantity yang ditolak

Penerimaan material yang kurang teliti di site dapat mengkibatkan ditolaknya sebagian material yang tidk memenuhi persyaratan mutu, bentuk, warna dan lainlain.

3. Quantity yang rusak

Penyimpanan materil yang kurang baik dapat menyebabkan kerusakan khususnya untuk material yang sangat dipengaruhi oleh kondisi lingkungan (temperature, kelembaban udara, tekanan dan lain-lain). Kerusakan material juga dapat terjadi karena kegiatan pengambilan, pengangkutan, pengangkatan dan pemasangan yang kurang baik.

4. Quantity yang hilang

Material-material yang mudah dijual di pasaran atau banyak diperlukan oleh masyarakat (seperti semen dan lain-lain) rawan hilang akibat pencurian. Sistem pengamanan yang lemah dengan system control yang lemah akan memperbesar kemungkinan hilangnya material-material tersebut. Material fiktif (quantity ada tapi fisiknya tidak ada), termasukdalam kelompok quantity yang hilang.

5. Quantity akibat kelebihan penggunaan

Waste jenis ini biasanya dilakukan oleh pelaksana yang menggunakan material secara langsung, waste ini juga dapat disebabkan oleh over method, over quality atau ketidaktelitian tentang ukuran/dimensi, sehingga dimensi pekerjaan yang terjadi lebih besar dari gambar. Kelebihan penggunaan material juga dapat disebabkan oleh metode yang kurang efisien dan juga akibat pekerjaan berulang.

\section{METODE PENELITIAN}

\subsection{Objek Penelitian}

Penelitian dilakukan pada proyek konstruksi di Kota Padang, baik yang sudah selesai maupun yang sedang berjalan dalam kurun waktu 4 tahun terakhir.

\subsection{Metode Penelitian}

Metode yang dipakai dalam adalah metode Studi Kasus. Desain penelitian adalah logika keterkaitan antara data yang harus dikumpulkan 
dan pertanyaan awal suatu penelitian.

\subsection{Metode Pengumpulan dan Pengujian Data}

\subsubsection{Metode Pengumpulan Data}

Metodologi dalam pengumpulan data adalah quisioner. Respondennya adalah semua pihak yang terlibat dalam proyek konstruksi seperti site manager, project manager, kepala pelaksana dan pelaksana.

Butir-butir pertanyaan quisioner merupakan faktor-faktor (yang dianggap sebagai variabel bebas $=\mathrm{X}_{\mathrm{i}}$ ) dapat dilihat pada Tabel 2.1. Sedangkan skala yang dipakai adalah skala Likert (Nazir, 1988) yaitu :

- Sangat tidak berpengaruh. (nilai 1)

- Tidak berpengaruh

- Sedang. (nilai 3)

- Berpengaruh ..(nilai 4)

- Sangat berpengaruh.................(nilai 5) Sedangkan sebagai variable terikatnya (Y) adalah perbedaan estimasi biaya awal dengan biaya pelaksanaan.

Tabel 2.1. Faktor-Faktor Construction Waste

\begin{tabular}{|c|c|c|c|}
\hline No & $\begin{array}{l}\text { Faktor } \\
\text { Waste }\end{array}$ & Sub Faktor Waste & $\begin{array}{l}\text { Variabel } \\
\text { Bebas }\end{array}$ \\
\hline \multirow{7}{*}{1} & \multirow{7}{*}{$\begin{array}{l}\text { Waktu } \\
\text { Tunggu }\end{array}$} & Waktu menunggu instruksi & $\mathrm{X}_{1}$ \\
\hline & & Waktu menunggu material & $\mathrm{X}_{2}$ \\
\hline & & $\begin{array}{l}\text { Waktu menunggu perbaikan } \\
\text { peralatan }\end{array}$ & $\mathrm{X}_{3}$ \\
\hline & & $\begin{array}{l}\text { Waktu menunggu datangnya alat } \\
\text { ke lokasi }\end{array}$ & $\mathrm{X}_{4}$ \\
\hline & & $\begin{array}{l}\text { Waktu menunggu datang nya } \\
\text { pekerja ke lokasi }\end{array}$ & $\mathrm{X}_{5}$ \\
\hline & & Waktu menunggu perbaikan & $\mathrm{X}_{6}$ \\
\hline & & $\begin{array}{l}\text { Waktu menunggu revisi } \\
\text { gambar/perubahan desain }\end{array}$ & $\mathrm{X}_{7}$ \\
\hline \multirow{7}{*}{2} & \multirow{7}{*}{$\begin{array}{l}\text { Material } \\
\text { / } \\
\text { Bahan }\end{array}$} & Kelebihan material/bahan & $\mathrm{X}_{8}$ \\
\hline & & $\begin{array}{l}\text { Material tidak sesuai dengan } \\
\text { spesifikasi }\end{array}$ & $\mathrm{X}_{9}$ \\
\hline & & Kehilangan material di lokasi & $\mathrm{X}_{10}$ \\
\hline & & Penumpukan material di lokasi & $\mathrm{X}_{11}$ \\
\hline & & $\begin{array}{l}\text { Sering terjadi pemindahan material } \\
\text { di lokasi }\end{array}$ & $\mathrm{X}_{12}$ \\
\hline & & Sisa material/bahan berserakan & $\mathrm{X}_{13}$ \\
\hline & & Kerusakan material/bahan di lokasi & $\mathrm{X}_{14}$ \\
\hline \multirow{3}{*}{3} & \multirow{3}{*}{$\begin{array}{l}\text { Sumber } \\
\text { Daya } \\
\text { Manusia }\end{array}$} & $\begin{array}{l}\text { Pekerja yang lambat/tidak } \\
\text { efektif/tidak disiplin }\end{array}$ & $\mathrm{X}_{15}$ \\
\hline & & Kurangnya skill tenaga kerja & $\mathrm{X}_{16}$ \\
\hline & & Pendistribusian tenaga kerja yang & $\mathrm{X}_{17}$ \\
\hline
\end{tabular}

\begin{tabular}{|c|c|c|c|}
\hline & & buruk & \\
\hline & & Mutu pengawasan rendah & $\mathrm{X}_{18}$ \\
\hline & & $\begin{array}{l}\text { Kemampuan sub kontraktor yang } \\
\text { rendah }\end{array}$ & $\mathrm{X}_{19}$ \\
\hline & & Tenaga kerja yang menganggur & $\mathrm{X}_{20}$ \\
\hline & & Kesalahan instruksi pekerjaan & $\mathrm{X}_{21}$ \\
\hline & & $\begin{array}{l}\text { Kesalahan pada saat pelaksanaan } \\
\text { pekerjaan }\end{array}$ & $\mathrm{X}_{22}$ \\
\hline & & Terjadi kecelakaan kerja & $\mathrm{X}_{23}$ \\
\hline & & Peralatan sering rusak & $\mathrm{X}_{24}$ \\
\hline & & Peralatan tidak bisa diandalkan & $\mathrm{X}_{25}$ \\
\hline 4 & $\begin{array}{l}\text { Pelaksa } \\
\text { naan }\end{array}$ & $\begin{array}{l}\text { Keterlambatan pelaksanaan } \\
\text { pekerjaan }\end{array}$ & $\mathrm{X}_{26}$ \\
\hline 4 & $\begin{array}{l}\text { Konstru } \\
\text { ksi }\end{array}$ & $\begin{array}{l}\text { Tidak lengkapnya dokumen } \\
\text { kontrak }\end{array}$ & $\mathrm{X}_{27}$ \\
\hline & & $\begin{array}{l}\text { Pengukuran dilapangan tidak } \\
\text { akurat }\end{array}$ & $\mathrm{X}_{28}$ \\
\hline & & $\begin{array}{l}\text { Terjadi penambahan jenis } \\
\text { pekerjaan }\end{array}$ & $\mathrm{X}_{29}$ \\
\hline & & Pekerjaan rework dan repair & $\mathrm{X}_{30}$ \\
\hline nilai & 1) & $\begin{array}{l}\text { Perencanaan dan penjadwalan } \\
\text { yang buruk }\end{array}$ & $\mathrm{X}_{31}$ \\
\hline & & $\begin{array}{l}\text { Informasi yang diberikan kurang } \\
\text { jelas }\end{array}$ & $\mathrm{X}_{32}$ \\
\hline 5 & $\begin{array}{l}\text { Manaje } \\
\text { men }\end{array}$ & $\begin{array}{l}\text { Koordinasi yang buruk diantara } \\
\text { pihak-pihak yang terlibat dalam } \\
\text { proyek }\end{array}$ & $\mathrm{X}_{33}$ \\
\hline & & $\begin{array}{l}\text { Pengambilan keputusan yang } \\
\text { lambat }\end{array}$ & $\mathrm{X}_{34}$ \\
\hline & & $\begin{array}{l}\text { Metode konstruksi yang tidak } \\
\text { tepat/tidak sesuai }\end{array}$ & $X_{35}$ \\
\hline & & Spesifikasi yang tidak jelas & $\mathrm{X}_{36}$ \\
\hline & & Gambar kerja yang tidak jelas & $\mathrm{X}_{37}$ \\
\hline 6 & $\begin{array}{l}\text { Desain } \\
\text { dan }\end{array}$ & Pendetailan gambar yang rumit & $\mathrm{X}_{38}$ \\
\hline & $\begin{array}{l}\text { Dokume } \\
\text { ntasi }\end{array}$ & $\begin{array}{l}\text { Revisi dan distribusi gambar yang } \\
\text { lambat }\end{array}$ & $\mathrm{X}_{39}$ \\
\hline & & Perubahan desain & $\mathrm{X}_{40}$ \\
\hline & & Desain yang buruk & $\mathrm{X}_{41}$ \\
\hline & & Kondisi lokasi yang tidak bagus & $\mathrm{X}_{42}$ \\
\hline 7 & $\begin{array}{l}\text { Ekstern } \\
\text { al }\end{array}$ & Cuaca & $\mathrm{X}_{43}$ \\
\hline & & $\begin{array}{l}\text { Kerusakan/kehilangan oleh pihak } \\
\text { lain }\end{array}$ & $\mathrm{X}_{44}$ \\
\hline Fak & Penyebal & Construction Waste & $\mathrm{Y}$ \\
\hline
\end{tabular}

\subsubsection{Metode Pengujian Data}

Pengolahan data dilakukan dengan menggunakan program statistik SPSS (Statistic Program for Social Science) ver 16, meliputi :

\section{Pengujian Validitas}


Menurut Chang (2002), variabel dikatakan valid jika mempunyai nilai corrected item-total correlation $\geq 0,360$.

\section{Pengujian Reliabilitas}

Teknik uji reliabilitas yang dapat digunakan adalah teknik konsistensi internal dengan metode stabilitas alpha cronbach. Instrumen tersebut dinyatakan reliabel atau cukup handal apabila memiliki cronbach alpha lebih dari 0,60 (Chang, 2002).

\section{Pengujian Korelasi}

Besaran tingkat hubungan korelasi dianggap kuat jika mempunyai nilai koefisien korelasi $(\mathrm{R}) \geq 0.5$ (Santoso, 1999).

\subsection{Analisis Data}

Analisa data diselesaikan dengan analisa regresi linier berganda. Model persamaan regresi adalah:

$Y=a+b_{1} \cdot X_{1}+b_{2} \cdot X_{2}+\ldots \ldots \ldots \ldots \ldots .$. $b_{n} \cdot X_{n}$

dimana :

$$
\begin{aligned}
& Y=\text { Variabel Terikat } \\
& X=\text { Variabel Bebas } \\
& a=\text { Konstanta } \\
& b=\text { Koefisien Regresi }
\end{aligned}
$$

\section{Uji Model Regresi :}

\section{1. $\mathbf{U j i}^{2} \mathbf{R}^{2}$}

$\mathrm{R}^{2}$ test digunakan untuk mengukur besarnya kontribusi variabel bebas $\mathrm{X}$ terhadap variasi (naik turunnya) variabel terikat Y.(Santoso, 1999).

\section{Uji F}

Uji ini dilakukan untuk menentukan signikasi pengaruh variabel bebas bersama-sama terhadap variabel terikat. Jika tingkat signifikan $\leq 0,05$, berarti variabel bebas mempunyai pengaruh yang signifikan terhadap variabel terikat.

\section{Uji t}

Tujuan dari Uji t (Student-t Distribution) adalah untuk mengetahui tingkat kepercayaan tiap variabel bebas dalam persamaan atau model regresi yang digunakan dalam memprediksi nilai Y.

\section{HASIL DAN PEMBAHASAN}

\subsection{Hasil}
$\mathrm{Y}=3,866+0,782 \mathrm{X}_{7}+\mathbf{0 , 4 3 0 \mathrm { X } _ { 1 8 } +}$ $1,957 X_{22}+2,122 X_{26}+0,556 X_{30}+$ $2,730 X_{31}+0,863 X_{40}+0,966 X_{43}$

\subsection{Pembahasan}

Teridentifikasi 7 faktor dan 44 variabel penyebab waste konstruksi. Setelah dilakukan uji validasi, dari 7 faktor dan 44 variabel tersebut hanya 5 faktor dan 37 variabel yang valid. Setelah dilanjutkan dengan pengujian reliabilitas, didapatkan 5 faktor dan 14 variabel yang reliabel. Hasil uji korelasi, teridentifikasi 5 faktor dan 14 variabel yang mempunyai hubungan yang kuat (semua yang reliable terkorelasi dengan kuat).

Setelah dilakukan pengujian validasi, reliabilitas dan korelasi, dilanjutkan dengan analisa regresi. Analisa regresi dilakukan dengan uji $\mathrm{R}^{2}$, uji $\mathrm{F}$ dan uji t. Dari hasil uji $\mathrm{R}^{2}$, didapatkan besarnya kontribusi 14 variabel terhadap variasi waste konstruksi sebesar 91,6\%. Hasil uji F memperlihatkan secara simultan semua variabel mampu menjelaskan hubungannya terhadap waste konstruksi dengan sangat baik. Hal ini ditunjukkan oleh signifikasi $<5 \%$. Dari 5 faktor dan 14 variabel, setelah dilakukan uji t, teridentifikasi 5 faktor dan 8 variabel yang signifikan.

Dari persamaan regresi, didapatkan besarnya variabel yang memberikan kontribusi terhadap waste konstruksi pelaksanaan proyek adalah $\mathrm{X}_{7}$ (waktu menunggu revisi gambar/perubahan desain) sebesar $0,782, \mathrm{X}_{18}$ (mutu pengawasan rendah) sebesar 0,$430 ; X_{22}$ (kesalahan pada saat pelaksanaan pekerjaan) sebesar 1,$957 ; \quad X_{26}$ (keterlambatan pelaksanaan pekerjaan) sebesar 2,122; $\quad \mathrm{X}_{30}$ (pekerjaan rework dan repair) 
sebesar 0,556; $\quad \mathrm{X}_{31}$ (perencanaan dan penjadwalan yang buruk) sebesar 2,730; $\mathrm{X}_{40}$ (perubahan desain) sebesar 0,863 dan $\mathrm{X}_{43}$ (cuaca) sebesar 0,966.

\section{KESIMPULAN}

1. Waste konstrusi dapat berpengaruh buruk terhadap pelaksanaan konstruksi terutama berhubungan dengan biaya dan waktu pelaksanaan pekerjaan.

2. Metode penelitian adalah studi kasus dengan menyebarkan quisioner yang berisi butir-butir pertanyaan tentang waste konsruksi, sebanyak 25 quisioner. Dan responden rate adalah $100 \%$.

3. Hasil uji validasi, dari 7 faktor dan 44 variabel, teridentifikasi hanya 5 faktor dan 37 variabel yang valid.

4. Hasil uji reliabilitas, dari 5 faktor dan 37 variabel, teridentifikasi 5 faktor dan 14 variabel yang reliabel.

5. Hasil uji korelasi, semua variable yang reliable ternyata semua teridentifikasi kuat yaitu 5 faktor dan 14 variabel.

6. Hasil uji $\mathrm{R}^{2}$, didapatkan besarnya kontribusi 14 variabel terhadap waste konstruksi sebesar 91,6\%.

7. Hasil uji F memperlihatkan secara simultan 14 variabel tersebut mampu menjelaskan hubungannya terhadap penyimpangan biaya dengan sangat baik.

8. Hasil uji t, didapat bahwa bahwa variabel yang memberikan kontribusi terbesar terhadap waste konstruksi pelaksananan proyek adalah waktu menunggu revisi gambar/perubahan desain sebesar 0,782 , mutu pengawasan rendah sebesar 0,430 , kesalahan pada saat pelaksanaan pekerjaan sebesar 1,957, keterlambatan pelaksanaan pekerjaan sebesar 2,122, pekerjaan rework dan repair sebesar 0,556, perencanaan dan penjadwalan yang buruk sebesar 2,730, perubahan desain sebesar 0,863 dan cuaca sebesar 0,966 .

\section{DAFTAR PUSTAKA}

Asiyanto (2005), "Construction Project Cost Manajement", Pradnya Paramita, Jakarta.

Hadiman, 2014, "Evaluasi Waste pada Proyek Gedung di Wilayah Semarang"

http://digilib.its.ac.id/public/ITS-Master-189433108203005-Presentation.pdf

http://e-journal.uajy.ac.id/1234/1/0TS13008.pdf http://eprints.undip.ac.id/46371/

Kaming Peter F, 2014, "Construction Waste pada Proyek-Proyek Konstruksi di Daerah Istimewa Yogyakarta"

Messah Y, 2011, "Kajian Hubungan Waste Material Konstruksi dan Organisasi Proyek Konstruksi"

Purnatha J, 2013, "Studi Mengenai Construction Waste pada Proyek Konstruksi di Kabupaten Badung"

Santoso, S (1999), "SPSS - Mengolah Data Secara Professional", Elex Media Komputindo, Jakarta.

Trisiana A, 2011, "Analisa Faktor Resiko Waste pada Proyek Konstruksi Gedung di Kota Jember" 